Available online on 15.12.2019 at http://ajprd.com

Asian Journal of Pharmaceutical Research and Development

Open Access to Pharmaceutical and Medical Research

(C) 2013-19, publisher and licensee AJPRD, This is an Open Access article which permits unrestricted noncommercial use, provided the original work is properly cited

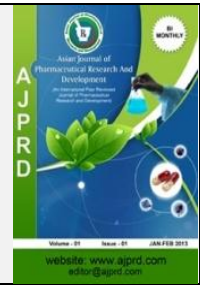

Open $\mathcal{O}_{\text {Access }}$

Research Article

\title{
Antiinflammatory Activity of Pagoda Flower (Clerodendrum Paniculatum L.) Ethanol Extract Using Paw Edema Method
}

\section{Ihsanul Hafiz*, Mandike Ginting}

Faculty of Pharmacy and Health, Institut Kesehatan Helvetia,Kapten Sumarsono Street 107, Medan, Sumatera Utara, Indonesia

\begin{abstract}
A B S T R A C T
Objectives: The purpose of this study was to determine antiinflammatory activity of pagoda flower (Clerodendrum paniculatum L.) ethanolic extract

Design: This study uses an experimental laboratory design. This research uses paw edema method by inducing carrageenin in the legs of male white rats as an induction of inflammation.

Interventions: The sample used was pagoda flower ethanol extract in various dosages of 25, 50 and $100 \mathrm{mg} / \mathrm{kg}$. As a comparison, acetosal dose $33 \mathrm{mg} / \mathrm{kg}$ was used. Na CMC suspension was used as a negative control.

Main outcome measure: The results in this study are the difference in the volume of edema volume from rat feet per unit time. The measurement of the rat's leg volume was measured at 30,60,120, 180, 240 and 300 minutes.

Conclusion: Pagoda flower ethanol extract does not have good anti-inflammatory activity. there were no significant differences between groups except at dose 100 and positive control at minute 300 of negative control.
\end{abstract}

Keywords: antiinflammatory activity, Clerodendrum paniculatum L., paw edema

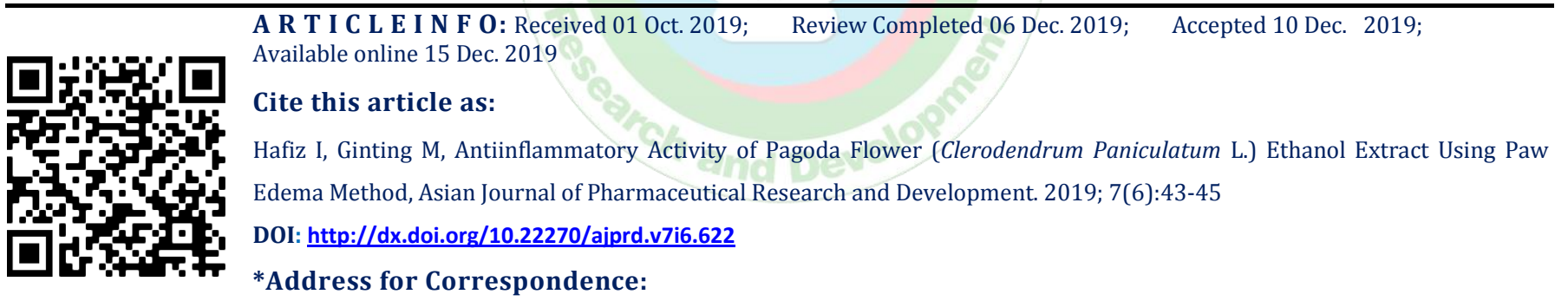

Ihsanul Hafiz, Faculty of Pharmacy and Health, Institut Kesehatan Helvetia,Kapten Sumarsono Street 107, Medan, Sumatera Utara, Indonesia

\section{INTRODUCTION}

$\mathrm{T}$ The antiinflammatory activity of the pagoda plant was tested in 2016. The ethanol extracts of the pagoda leaves were active at a dose of $50 \mathrm{mg} / \mathrm{kg}$. In addition to having anti-inflammatory activity, ethanol extract of pagoda leaves also has a very strong antioxidant activity of $27.73376 \mu \mathrm{g} / \mathrm{ml}^{1}$. Similar plants in the genus Clerodendrum which have antiinflammatory activity include C.Phlomidis, C. Serratum, C.Trichotomum, C. Chinense, C. Petasites, C. inerme, and C. viscosum ${ }^{2-6}$.

Besides having antiinflammatory and antioxidant activity, $C$. paniculatum has been measured its pharmacological potential using the Brine shrimp Lethality Toxicity (BSLT) toxicity test, the result is that the ethanol extract of the pagoda flower has a strong activity potential as evidenced by $\mathrm{LC}_{50}$ value of $45,487 \mathrm{ppm}^{7}$.

In 2019 an anti-inflammatory activity test was carried out on the ethanol extract of pagod flowers as a follow-up study from previous studies.

\section{MATERIALS AND METHODS}

\section{Plant and Chemical Materials}

The pagoda used in this study was obtained from the Pancur Batu area in Deli Serdang Regency, North Sumatra, Indonesia. The part of the plant used is flowers. Pagoda 
flowers have been determined by the Herbarium Bogoriense Indonesian Institute of Science and it is known that the species is Clerodendrum paniculatum L. with Familia Lamiaceae.

The tools used in this study were glassware (pyrex), $1 \mathrm{ml}$ syringes, oral sonde, analytical scales, rotary evaporator and plethismometer.

The chemicals used in this study were ethanol, carragenin kappa, CMC sodium, and acetosal (Aspilets ${ }^{\circledR}$ ) from DaryaVaria.

\section{Plant Extraction}

Pagoda flower extraction uses maceration method which is a number of pagoda flower simplicia soaked in $96 \%$ ethanol solvent for 3 days while stirring occasionally. Maserate and residue are separated and filtered, then the pulp is washed using the same solvent until a total of 10 times the weight of the simplicia is obtained. Maserates are collected and allowed to stand for 24 hours without stirring, then separate the clear solution with the precipitate. Clear solution was thickened using a rotary evaporator until a thick extract was obtained $^{8,9}$.

\section{Measurement of Antiinfllammatory Activity}

Test animals used were male white rat species of Rattus novergicus wistar strain with 2-3 months of age and body weight 150-200 g. These test animals are commonly used in testing pharmacological activities. This study has fulfilled the requirements of the ethics committee regarding the use of test animals in research ${ }^{10,11}$.

This study used 25 test animals which were divided into 5 groups. The first group was given sodium CMC suspension as a negative control, the second group was given acetosal 33 $\mathrm{mg} / \mathrm{kg}$ as a positive control, and the other group was given ethanol extract of pagoda flowers in doses of 25, 50 and 100 $\mathrm{mg} / \mathrm{kg}$.

Antiinflammatory activity was tested using the paw edema method in which the rat's feet were swollen with carragenan kappa which was injected into the sole of the rats feet. Test samples in the form of extracts and comparison compounds were given to each test animal 30 minutes before inducing carragenane. Then the volume of the feet of rats was measured in minutes $0,30,60,120,180,240$, and 300 . Based on the measurement results the difference in foot volume was calculated from 30 to 300 minutes to the initial volume (minute 0 ). The results of the study were analyzed using the ANOVA method to see differences between groups.

\section{RESULT AND DISCUSSION}

Antiinflammatory research result from the ethanol extract of the pagoda flower can be seen in table 1 .

Table 1: Antiinflammatory activity of $C$. paniculatum ethanol extract

\begin{tabular}{|l|l|l|l|l|l|l|l|}
\hline \multirow{2}{*}{ No } & \multirow{2}{*}{ Groups } & \multicolumn{6}{|l|}{ Difference of Edema Volume (ml) per Time (Minutes) \pm Error Standard } \\
\cline { 3 - 8 } & & $\mathbf{3 0}$ & $\mathbf{6 0}$ & $\mathbf{1 2 0}$ & $\mathbf{1 8 0}$ & $\mathbf{2 4 0}$ & $\mathbf{3 0 0}$ \\
\hline 1 & Negative control & $0.00 \pm 0.00$ & $0.00 \pm 0.00$ & $0.03 \pm 0.03$ & $0.14 \pm 0.04$ & $0.23 \pm 0.03$ & $0.27 \pm 0.03$ \\
\hline 2 & Positive control & $0.00 \pm 0.00$ & $0.10 \pm 0.06$ & $0.10 \pm 0.06$ & $0.07 \pm 0.03$ & $0.03 \pm 0.03$ & $0.03 \pm 0.03^{*}$ \\
\hline 3 & Extract $25 \mathrm{mg} / \mathrm{kg}$ & $0.00 \pm 0.00$ & $0.07 \pm 0.07$ & $0.07 \pm 0.07$ & $0.13 \pm 0.07$ & $0.20 \pm 0.06$ & $0.20 \pm 0.06$ \\
\hline 4 & Extract $50 \mathrm{mg} / \mathrm{kg}$ & $0.07 \pm 0.03$ & $0.17 \pm 0.03$ & $0.17 \pm 0.03$ & $0.17 \pm 0.03$ & $0.10 \pm 0.06$ & $0.10 \pm 0.06$ \\
\hline 5 & Extract $100 \mathrm{mg} / \mathrm{kg}$ & $0.07 \pm 0.07$ & $0.13 \pm 0.07$ & $0.13 \pm 0.07$ & $0.07 \pm 0.07$ & $0.07 \pm 0.03$ & $0.13 \pm 0.03^{*}$ \\
\hline
\end{tabular}

*significantly different with negative control (p value $\leq 0.05$ )

Based on the results of the study it was found that the antiinflammatory activity possessed by the active pagoda flower ethanol extract at the 300th minute and started at a dose of $100 \mathrm{mg} / \mathrm{kg}$. At 30 to 240 minutes there were no differences between groups. Antiinflammatory activity of the pagoda flower ethanol extract is smaller than the activity of the pagoda leaf ethanol extract. The Pagoda leaves reduce inflammation or active as an antiinflammatory at a dose of 50 $\mathrm{mg} / \mathrm{kg}$ at the 30th minute ${ }^{1}$. The root extract of $C$. paniculatum possessed the anti-inflammatory potential by reducing the release of inflammatory mediators $\left(\mathrm{NO}, \mathrm{PGE}_{2}\right)$ and pro-inflammatory cytokine (TNF- $\alpha)^{12}$.

Peak edema develops within the first 3 to 4 hours, and is inhibited by pretreatment of the animals by single oral doses of antiinflammatory agents, steroid or non-steroid. Log dose responses to drugs are linear and parallel, and yield potency ratios with relatively narrow confidence limits. The potency ratios obtained for aspirin, phenylbutazone and hydrocortisone are fairly close to the ratios of their respective daily doses in the treatment of rheumatic disease. A potent antihistaminic-antiserotonin compound, cyproheptadine, is without effect on carrageenin-induced edema ${ }^{13}$.

\section{CONCLUSSION}

Pagoda flower ethanol extract does not have good antiinflammatory activity. there were no significant differences between groups except at dose 100 and positive control at minute 300 of negative control.

\section{CONFLICT OF INTEREST}

All author have no to declare.

\section{ACKNOWLEDGEMENT}

The author are thank full to the Directorate of Research and Community Service (DRPM), the Directorate General of Research and Development Strengthening, the Indonesian Ministry of Research and Higher Education (Kemenristekdikti) for the research funding provided. 


\section{REFERENCES}

1. Hafiz I, Rosidah, Silalahi J. Antioxidant and anti-inflammatory activity of pagoda leaves (clerodendrum paniculatum 1.) ethanolic extract in white male rats (Rattus novergicus). Int J PharmTech Res. 2016; 9(5):165-170.

2. Matsushima K, Terashima Y, Toda E, Shand F, Ueha S. Chemokines in inflammatory and immune diseases. Inflamm Regen. 2011;31(1):11-22.

3. Yankanchi SR, Koli SA. Anti-inflammatory and Analgesic activity of mature leaves methanol extract of Clerodendrum inerme L.(Gaertn). J Pharm Sci Res. 2010; 2(11):782.

4. Bhangare NK, Pansare TA, Ghongane BB, Nesari TM. Screening for antiinflammatory and anti-allergic activity of Bharangi \{Clerodendrum serrratum (Linn.) moon \} in animals. Int J Pharma Bio Sci. 2012; 3(4): 245-54.

5. Parekar RR, Dash KK, Marathe PA, Apte AA, Rege NN. Evaluation of antiinflammatory activity of root bark of Clerodendrum phlomidis in experimental models of inflammation. International Journal of Applied Biology and Pharmaceutical Technology. 2012; 3(3):55-60.

6. Chandrashekar R, Rao SN. Chronic anti-inflammatory activity of ethanolic extract of leaves of Clerodendrum viscosum by carrageenin induced paw oedema in Wistar albino rats. Br J Pharm Res. 2013 ;3(4):579.

7. Hafiz I. The Phytochemical Screning and Assesment of Bioactivity of Pagoda Flower (Clerodendrum paniculatum L.) Using Brine Shrimp (Artemia salina)
Lethality Assay. Asian J Pharm Res Dev. 2019; 7(3):10-3.

8. Azwanida NN. A review on the extraction methods use in medicinal plants, principle, strength and limitation. Med Aromat Plants. 2015; 4(196):412-2167.

9. Lemaire C, Plenevaux A, Aerts J, Del Fiore G, Brihaye C, Le Bars D, et al. Solid phase extraction - an alternative to the use of rotary evaporators for solvent removal in the rapid formulation of PET radiopharmaceuticals. J Label Compd Radiopharm Off J Int Isot Soc. 1999; 42(1):63-75.

10. Carvalho GD, Masseno APB, Zanini MS, Zanini SF, Porfirio LC, Machado $\mathrm{JP}$, et al. Clinical evaluation of laboratory rats (Rattus novergicus Wistar strain): sanitary biological and physiological parameters. Rev Ceres. 2009; 56(1):51-7.

11. Fraser D. Animal ethics and animal welfare science: bridging the two cultures. Appl Anim Behav Sci. 1999; 65(3):171-89.

12. Phuneerub P, Limpanasithikul W, Palanuvej C, Ruangrungsi N. In vitro antiinflammatory, mutagenic and antimutagenic activities of ethanolic extract of Clerodendrum paniculatum root. J Adv Pharm Technol Res. 2015; 6(2):48.

13. Winter CA, Risley EA, Nuss GW. Carrageenin-induced edema in hind paw of the rat as an assay for antiinflammatory drugs. Proc Soc Exp Biol Med. 1962; 111(3):544-7. 